\title{
PERADILAN PIDANA PRESPEKTIF ABOLISIONISME: KRITIK TERHADAP MODEL PEMIDANAAN FISIK MENUJU PEMIDANAAN PSIKIS
}

\author{
Hajairin, M.H.
}

Sekolah Tinggi Ilmu Hukum Muhammadiyah Bima Jln. Anggrek No. 16 Ranggo Na'e Kota Bima

hajairinbima91@gmail.com

\section{Abstract:}

Paham abolisionisme memunculkan kritikan terhadap prosedural peradilan pidana yang di anggap cacat sehingga pemidanaan yang di ciptakan tidak selamanya dapat di berikan sanksi pidana, seperti kasus-kasus tindak pidana ringan seperti pencurian ayam yang harganya kurang dari seratus ribu rupiah, namun karena prosedural yang cukup administrative dalam peradilan pidana sehingga pencuri ayam tersebut dapat di hukum sesuai dengan perbuatanya tampa kita perdulikan berapa anggaran Negara yang di habiskan dalam penangan perkara pencurian ayam yang nominalnya cukup besar. Fokus permasalahan dalam penelitian ini adalah Konsep Peradilan Pidana Prespektif Abolisionisme dari Pemidanaan Fisik Menuju Pemidanaan Psikis, dengan Metode penelitian yang di gunakan dalam menjawab masalah tersebut menggunakan jenis penelitian hukum normative dengan pendekatan konseptual dan sosiologi hukum, sementara sumber bahan hukum yakni bahan hukum primer dan bahan hukum sekunder dengan teknik pengumpulan bahan hukum dilakukan dengan cara menganalisis asas-asas, konsepsi-konsepsi, pandanganpandangan, doktrin-doktrin hukum serta isi kaidah hukum 
sementara konsep analisis bahan hukum yaitu dengan cara analisis yuridis konseptual. Hasil penelitian ini menunjukan bahwa Pemikiran abolisionisme ini dapat dijadikan dasar perubahan paradigma dalam pemberian sanksi pidana melalui peradilan pidana, dari model pemidanaan yang bersifat fisik menuju model pemidanaan yang bersifat psikis, hal ini bertujuan untuk memberikan keseimbangan hukum yang bermuara pada tegaknya nilai keadilan dan ketertiban sosial, sebab dalam konsep pemidanaan kita perlu menjelaskan tentang tujuan pemidanaan yang memberikan ketertiban sosial, seperti pemidanaan itu harus bisa merubah pola pikir dan perilaku manusia melalui pemidanaan itu sendiri dengan contoh pencuri ayam tersebuh dapat menyadari perbuatannya dan tidak mengulangi perbuatan yang sama, paham abolisionisme mencoba merubah pandangan manusia dari pemidanaan yang berfokus pada pemidanaan fisik menuju pemidanaan psikis sebagai tujuan dari pemidanaan.

\section{Keywords: Peradilan Pidana, Abolisionisme, Model Pemidanaan}

\section{Pendahuluan}

Dalam penegakan hukum pidana perlu dipertimbangkan nilai kepastian hukum dan ketertiban sosial, sebagai bagian dari hukum diciptakan bukan untuk memberikan penderitaan pada manusia, melainkan diciptakan untuk kemaslahatan umat manusia, paham abolisionisme selain menganggap peradilan pidana yang cacat secara prosedural juga menganggap peradilan pidana yang cacat secara struktural, namun paham abolisionisme kritikanya berfokus pada bentuk pemidanaan dalam kategori tindak pidana ringan (Tipiring). Kritikan ini muncul dengan memperhatikan beberapa perbuatan pidana yang tidak 
selamanya dapat di jatuhi pidana, seperti kasus-kasus pencurian ayam yang harganya kurang dari seratus ribu rupiah, yang di proses secara administratif, hingga menghabiskan anggaran Negara yang cukup besar.

Dalam prespektif Hulsman paham abolisionisme melihat criminal justice system atau sistem peradilan pidana di pandang sebagai masalah sosial dengan mempertimbangkan sistem peradilan pidana memberikan penderitaan, sistem peradilan pidana tidak dapat bekerja sesuai dengan tujuan dan cita-citanya, sistem peradilan pidana tidak terkendali dan pendekatan yang di gunakana dalam sistem peradilan pidana memiliki cacat mendasar. Pemikiran abolisionisme ini mengacu pada faktor eksternal dari pelaku kejahatan, sebab orang melakukan kejahatan tidak saja disebabkan oleh masalah internal dirinya, tetapi lebih banyak disebabkan oleh masalah eksternal yang kemudian mempengaruhi ke dalam dirinya, sehingga yang diperlukan bukan pidana (punishment) terhadap dirinya, melainkan tindakan (treatment) perbaikan pada faktor psikologisnya.

Peradilan pidana kita saat ini perlu menggunakan pendekatan tertentu dan pemahaman yang komprehensif tetang konsep peradilan pidana, ruang lingkup peradilan pidana, tujuan peradilan pidana, dengan rekonstruksi peradilan pidana di masa lalu dan masa depan peradilan pidana, saat ini praktik peradilan pidana selalu di dominasi oleh model pembuktian, proses itulah yang di anggap bermasalah bagi paham abolisionisme sebab proses hukum bagi seseorang tanpa mempertimbangkan aspek lainya dalam penegakan hukum pidana, padahal tujuan penegakan hukum itu adalah untuk menciptakan kesejahteraan masyarakat melalui sistem yang bernama hukum. Sebagai suatu Negara hukum yang mempunyai landasan filosofi (groundnorm) yang kuat, sudah selayaknya Indonesia melakukan perubahanperubahan hukum secara komprehensif dan multi-dimensional 
yang didasarkan pada nilai-nilai kebersamaan demi mencapai tujuan akhir yang dicita-citakan oleh negara hukum, yaitu walfare state (negara sejahtera).

Dalam menafsirkan tujuan pemidanaan perlu mendapatkan perhatian khusus, agar selaras dengan tujuan hukum itu sendiri, selama ini masalah pemidanaan kita selalu berfokus pada berapa banyak hukuman yang dijatuhkan kepada seorang pencuri, meski setelah hukuman itu dijatuhkan pencuri tersebut justru akan melakukan pencurian yang lebih besar. Atas dasar itulah muncul pertanyaan yang paling mendasar yakni untuk apa hukuman yang banyak kalau manusianya tidak bisa berubah, harusnya dalam konsep pemidanaan kita perlu menjelaskan tentang tujuan pemidanaan yang memberikan ketertiban sosial, seperti perbaikan pola pikir dan perilaku manusia melalui pemidanaan itu sendiri. Berdasarkan latar belakang diatas dalam penulisan ini mengangkat judul "Peradilan Pidana Prespektif Abolisionisme: Kritik Terhadap Model Pemidanaan Fisik Menuju Pemidanaan Psikis".

\section{Metode Penelitian}

Jenis penelitian ini adalah penelitian hukum normatif dengan menggunakan beberapa tipe penelitian hukum yaitu penelitian terhadap asas-asas hukum dan penelitian untuk menemukan hukum dalam arti konkrit yaitu dalam hal penegakan hukum pidana. Penelitian hukum dilakukan untuk mengemukakan hukum yang sesuai untuk diterapkan guna menyelesaikan suatu permasalahan, dalam metode pendekatan ini, penelitian difokuskan untuk mengkaji penerapan kaidahkaidah atau norma-norma dalam hukum positif. ${ }^{1}$ Pendekatan Yang Digunakan menggunakan pendekatan yang digunakan, yakni:

1 . Jhonny Ibrahim, 2014, Teori dan Metodologi Penelitian Hukum Normatif, Banyumedia Publishing, Surabaya, Hal, 295

Sangaji Jurnal Pemikiran Syariah dan Hukum 
1) Pendekatan Konseptual (conceptual approach) yaitu pendekatan yang di lakukan dengan mengkaji konsep-konsep hukum, teori-teori hukum dan pendapat para ahli yang ada kaitannya dengan peradilan pidana prespektif abolisionisme, kritik terhadap model pemidanaan fisik menuju pemidanaan psikis.

2) Pendekatan sosiologi hukum, merupakan pendekatan yang menganalisis tentang bagaiamana reaksi dan interaksi yang terjadi ketika sistem Norma itu bekerja dalam masyarakat. Pendekatan ini dikonstruksikan sebagai sesuatu perilaku masyarakat yang ejek terlembagakan serta mendapatkan legitimasi secara sosial dengan memperhatikan ketertiban sosial yang di wujudkan menggunakan pemanfaatan hukum sebagai sarana.

Sumber Bahan Hukum dapat di bagi dalam dua bahan hukum yakni Bahan hukum primer dalam penelitian ini berfokus pada konsep atau paham abolisionisme dalam peradilan pidana khusus dibidang pemidanaan dan Bahan hukum sekunder yaitu bahan yang memberikan penjelasan tentang konsep atau paham abolisionisme dalam peradilan pidana khusus dibidang pemidanaan. Teknik pengumpulan bahan hukum dilakukan dengan cara menganalisis asas-asas, konsepsi-konsepsi, pandangan-pandangan, doktrin-doktrin hukum serta isi kaidah hukum diperoleh melalui dua referensi utama yaitu a) Bersifat umum, terdiri dari buku-buku, teks, ensiklopedia b) Bersifat khusus, terdiri dari laporan hasil penelitian, majalah maupun jurnal yang berkaitan dengan peradilan pidana prespektif abolisionisme, kritik terhadap model pemidanaan fisik menuju pemidanaan psikis.

Sementara teknik analisis bahan hukum yang digunakan dalam penelitian ini adalah yuridis konseptual, yaitu dengan mengkaji paham berdasarkan aspek hukum tanpa menggunakan diagram ataupun statistic dan selanjutnya diberikan secara 
deskriptif dalam kalimat yang teratur dan logis. Kemudian data sekunder digunakan sebagai penunjang data primer untuk menarik suatu kesimpulan. ${ }^{2}$ Pemikiran dalam peradilan pidana prespektif abolisionisme, kritik terhadap model pemidanaan fisik menuju pemidanaan psikis.

\section{Paham Abolisionisme}

Di tengah usaha penanggulangan terhadap kejahatan dengan penggunaan sarana hukum pidana yang memunculkan rasa pesimistis dari pemikir abolisionisme yang sangat menentang penggunaan sarana hukum pidana yang sangat normative dalam menanggulangi kejahatan, sebab bila dibaratkan sebagai sebuah bangunan tubuh manusia, maka hukum formal yang berupa peraturan perundang-undangan hanyalah yang merupakan tulang-tulang yang menjadi kerangkan (sketch skeleton) saja bagi bangunan hukum itu sedangkan masyarakat bolehlah diibaratkan dagingnya, jadi ada kerangka dan dagingdagingnya, para ahli hukum senang menekuni kerangka bangunan itu dari pada mengkaji pula daging-dagingnya maupun urat-uratnya yang menempel pada kerang itu. ${ }^{3}$

Pemikir abolisionisme seperti Fillipo Gramatica dan Olof Kinberg melakukan gerakan revolusioner terhadap pandangan pemidanaan yang menekankan pada penderitaan terhadap fisik, yaitu menggunakan sarana pidana (punishment), ide penghapusan pidana yang paling ekstrim muncul dari Fillipo Gramatica pada tahun 1947 dalam tulisannya yang berjudul $\mathrm{La}$ lotta contra la pena (the fights against punishment) menegaskan hukum perlindungan sosial harus menggantikan hukum pidana yang ada sekarang, tujuan utama dari hukum perlindungan sosial

2 Soerjono Soekanto, 2002, Pengantar Penelitian Hukum, UI Press, Jakarta, Hal 112

3 Suteki, 2013, Desain Hukum Di Ruang Sosial, Thafa Media, Bantul Yogyakarta, Hal 1

Sangaji Jurnal Pemikiran Syariah dan Hukum 
adalah mengintegrasikan individu ke dalam tertib sosial dan bukan pemidanaan terhadap perbuatannya.

Kemudian Olof Kinberg juga memberikan pandangan sebagai tokoh abolisionis dalam bukunya Le droit de punir pada tahun 1948 yang mengatakan kejahatan pada umumnya merupakan perwujudan ketidaknormalan atau ketidakmatangan si pelanggar (the expression of an offenders's abnormality or immaturity) yang lebih memerlukan tindakan perawatan (treatment) dari pada pidana. Pemikiran kaum abolisionis ini sangat dipengaruhi oleh paham determinisme yang menyatakan bahwa orang tidak mempunyai kehendak yang bebas dalam melakukan perbuatan, karena dipengaruhi oleh watak pribadinya, faktor-faktor biologis dan faktor lingkungan kemasyarakatannya, dengan demikian sebenarnya kejahatan merupakan manisfestasi dari keadaan jiwa seseorang yang abnormal, oleh karena itu pelaku kejahatan tidak dapat dipersalahkan atas perbuatannya dan tidak dapat dikenakan pidana, ketidaknormalan organik dan mental tidak dapat diperbaiki dengan pidana, tetapi diperlukan tindakan (treatment).

Dalam temuan lain justru paham abolisionisme mulai dikembangkan oleh Louk Hulsman dari belanda ketika menjadi Ketua Hukum Pidana Dan Kriminologi di Universitas Erasmus, Rotterdam pada tahun 1964. Arah pemikiran Hulsman yang secara eksplisit memiliki prespektif abolisionis tampak nyata dalam sebuah pidato wisudanya (handhaving van recht: the maintenance of justice) dalam pidatonya sangat memperhatikan aspek kemanusiaan yang di pandangnya dapat dikikis oleh keadilan yang dicapai melalui pelaksanaan hukum pidana, bahkan beliau berpendapat bahwa hukum pidana seharusnya dipandang sebagai salah satu sarana untuk mencapai tujuan pencegahan dan perbaikan terhadap ketidakadilan dalam masyarakat. 


\section{Konsep Pemidanaan}

Pertumbuhan pemikiran mengenai tujuan dari pemidanaan itu, seringkali mendorong orang untuk menciptakan lembaga-lembaga pemidanaan, lembaga lembaga penindakan atau lembaga-lembaga kebijaksanaan yang baru, yang sebelumnya belum pernah dikenal orang di dalam praktek, agar lembaga-lembaga baru seperti itu dapat dipergunakan secara sah menurut hukum, maka sebaiknya lembaga-lembaga tersebut harus dituangkan terlebih dahulu di dalam suatu konsep hukum dan pemikiran hukum, kesibukan itu membuat permasalahan kita di bidang pemidanaan tidak bisa kita selesaikan dengan baik sampai saat ini.

Hubungan yang erat antara tujuan yang ingin dicapai orang dengan suatu pemidanaan dengan lembaga-lembaga pemidanaan, penindakan dan kebijaksanaan seperti dimaksudkan dapat dilihat secara jelas di dalam cara orang memperlakukan para terpidana di lembaga-lembaga pemasyarakatan dihubungkan dengan pemikiran-pemikiran orang mengenai pidana, yang tumbuh dalam sejarah, yakni dari pemikiran-pemikiran yang tidak manusiawi hingga pemikiranpemikiran yang menghendaki agar harkat dan martabat dari terpidana sebagai manusia itu tetap dihargai, walaupun ia telah melakukan sesuatu tindakan yang melawan hukum.

Sementara tujuan dari Pemidanaan menurut Sahardjo adalah menimbulkan rasa derita pada terpidana karena dihilangkannya kemerdekaan bergerak, membimbing terpidana agar bertobat dan mendidik supaya ia menjadi seorang anggota masyarakat sosialis di Indonesia yang berguna, secara umum alasan pemidanaan dapat digolongkan dalam tiga golongan pokok, yaitu golongan teori pembalasan, teori tujuan dan teori gabungan dalam Teori Absolut/Pembalasan, Pelaku tindak pidana mutlak harus ada pembalasan yang berupa pidana, jadi seseorang 
penjahat mutlak harus dipidana, ibarat pepatah yang mengatakan darah hutang pati nyaur pati, nyawa bersabung nyawa. ${ }^{4}$

Konsep Teori Absolut/Pembalasan Teori ini terbagi 3 (tiga) pertama Pembalasan berdasarkan tuntutan mutlak dan etika, penganut teori ini adalah Hegel mengatakan bahwa hukum adalah perwujudan dari kemerdekaan, sedangkan kejahatan adalah merupakan tantangan kepada hukum dan keadilan Pembalasan demi keindahan atau kepuasan. Teori ini dikemukakan oleh Herbert menyatakan bahwa merupakan tuntutan mutlak dari perasaan ketidak puasan masyarakat sebagai akibat dari kejahatan Kedua Pembalasan sesuai dengan ajaran Tuhan Teori ini dikemukakan oleh Stahl Gewin dan Thomas Aquino, mengemukakan bahwa kejahatan adalah merupakan pelangaran terhadap keadilan dan harus ditiadakan, mutlak harus diberikan penderitaan kepada penjahat, demi terpeliharanya pri keadilan Tuhan Ketiga Pembalasan sebagai kehendak manusia, teori ini dikemukakan oleh Jean Jacques Rousseau, Hugo De Groot, Grotius, Beccaria, Memandang Negara sebagai hasil dari kehendak manusia, mendasarkan pemidanaan juga sebagai perwujudan dari kehendak manusia.

Selanjutnya Teori Tujuan (Teori Relatif atau Teori Perbaikan) Suatu pidana dapat dijatuhkannya untuk menakut-nakuti calon penjahat atau penjahat yang bersangkutan, untuk memperbaiki atau menyingkirkan penjahat, teori ini terbagi 4 (empat) pertama Pencegahan terjadi suatu kejahatan dengan mengadakan ancaman pidana yang cukup berat untuk menakut-nakuti calon penjahat. Teori ini di kemukakan oleh Paul Anselm van Feuerbach kedua Perbaikan atau pendidikan bagi penjahat, penjahat diberikan pendidikan berupa pidana, agar ia kelak dapat kembali kelingkungan masyarakat dalam keadaan mental yang lebih baik dan berguna. Teori ini di kemukakan oleh

${ }^{4}$ Wiryono Prodjodikoro, 1986, Asas-asas Hukum Pidana di Indonesia, Eresco, Bandung, hlm. 21. 
Grolman, Van Krause Roder. Ketiga menyingkirkan penjahat dari lingkungan atau pergaulan masyarakat. Penjahat yang sudah kebal kepada ancaman pidana yang berupa usaha menakutnakuti, supaya dijatuhi perampasan kemerdekaan yang cukup lama, bahkan jika perlu dengan hukuman mati. Teori ini di kemukakan oleh Ferri dan Garofalo dan Keempat Menjamin ketertiban hukum, mengadakan norma-norma yang menjadi ketertiban umum. Teori ini dikemukakan oleh Frans Von Litz, Van Hamel, Simons.

Kemudian Teori Gabungan memberikan pemahaman bahwa penjatuhan suatu pidana harus memberikan rasa kepuasan, baik bagi hakim maupun kepada penjahat itu sendiri, disamping kepada masyarakat, harus ada keseimbangan antara pidana yang dijatuhkan dengan perbuatan pidana yang dilakukan, Pendapat penulis yang cocok untuk diterapkan di Indonesia adalah teori gabungan, karena lebih bersifat manusiawi dan seimbang serta mencerminkan rasa keadilan apabila diterapkan, hal tersebut juga selaras dengan Hak Asasi Manusia yang menyatakan bahwa, setiap orang berhak untuk bebas dari penyiksaan, penghukuman atau perlakuan yang kejam, tidak manusiawi, merendahkan derajat dan martabat kemanusiaannya.

\section{Konsep Peradilan Pidana Prespektif Abolisionisme}

Pemikiran abolisionisme ini dapat dijadikan dasar perubahan paradigma dalam pemberian sanksi pidana, dari model pemidanaan yang bersifat fisik menuju model pemidanaan yang bersifat psikis, hal ini bertujuan untuk memberikan keseimbangan hukum yang bermuara pada tegaknya nilai keadilan dan ketertiban sebab penggunaan sanksi pidana dalam menanggulangi kejahatan merupakan peninggalan dari kebiadaban kita masa lalu (a vestige of our savage past). ${ }^{5}$

5 Barda Nawawi Arief, 2010, Kebijakan Legislatif dalam Penanggulangan Kejahatan dengan Pidana Penjara, Genta, Yogyakarta Hal 18

Sangaji Jurnal Pemikiran Syariah dan Hukum 
Dari berbagai sejarah munculnya paham abolisionisme sebenarnya lebih menonjol mulai dikembangkan oleh Louk Hulsman dari belanda ketika menjadi Ketua Hukum Pidana Dan Kriminologi di Universitas Erasmus, Rotterdam pada tahun 1964. Arah pemikiran Hulsman yang secara eksplisit memiliki prespektif abolisionis tampak nyata dalam sebuah pidato wisudanya (handhaving van recht: the maintenance of justice) dalam pidatonya sangat memperhatikan aspek kemanusiaan yang di pandangnya dapat dikikis oleh keadilan yang dicapai melalui pelaksanaan hukum pidana, bahkan beliau berpendapat bahwa hukum pidana seharusnya dipandang sebagai salah satu sarana untuk mencapai tujuan pencegahan dan perbaikan terhadap ketidakadilan dalam masyarakat. Dalam prespektif Hulsman, criminal justice system atau sistem peradilan pidana di pandang sebagai masalah sosial dengan mempertimbangkan sistem peradilan pidana memberikan penderitaan, sistem peradilan pidana tidak dapat bekerja sesuai dengan tujuan dan cita-citanya, sistem peradilan pidana tidak terkendali dan pendekatan yang di gunakana dalam sistem peradilan pidana memiliki cacat mendasar. ${ }^{6}$

Sistem hukum dalam ruang sosial, menunjukan bahwa betapa sistem hukum itu tidak dapat di pisahkan dengan ruangruang sosial yang ada, kemasyarakatan yang dibangun atas dasar sistem hukum, lontaran kritik-kritik terhadap pelaksanaan peradilan pidana membawa renungan pemikiran baru untuk menawarkan pengembangan model peradilan pidana yang berciri yuridis ontologis berubah kearah model peradilan alternatif atau model kemudi (stuur model) dengan pendekatan

6 . Romli Atmasasmita, 2010, Sistem Peradilan Pidana Kontemporer, Jakarta, Kencana Hal 106-107 
yuridis orientasi pada ilmu pengetahuan tentang perilaku manusia. ${ }^{7}$

Dengan demikian paham abolisionisme menganggap bahwa peradilan pidana yang berorientasi pada pemberian hukuman bagi siapapun yang melakukan kejahatan masih mendapatkan kritikan sekaligus memiliki catatan yang harus diperbaiki, mulai dari dugaan terhadap seseorang melakukan perbuatan pidana sampai pada penjatuhan pemidanaan karena terbukti melakukan kesalahan, namun hal ini tidak semudah seperti yang kita bayangkan, kritikan paham abolisionisme ini selain penjatuhan pidana yang tidak efisien juga banyak berkaitan dengan prosedural yang mencederai keadilan sehingga tidak dapat tercipta ketertiban sosial sebagai cita-cita hukum, sehingga peradilan pidana kita di Inodensia perlu adanya pembaharuan dibidang pemidanaan dengan pertimbangan untuk apa prosedural di jalankan sementara keadilan tidak dapat di wujudkan.

\section{Pembaharuan Peradilan Pidana Perspektif Pemidanaan Fisik Menuju Pemidanaan Psikis}

Kebijakan pembaharuan hukum dalam sistem peradilan pidana sebetulnya tidak hanya memaksimalkan perlindungan terhadap martabat dan hak asasi manusia, akan tetapi haruslah di arahkan perubahan pola pikir dan perilaku manusia sebagai warga negara Indonesia untuk dapat memahami kebijakan hukum yang dapat menanggulangi kejahatan manusia, untuk pembangunan hukum pidana Nasional. ${ }^{8}$ Keberadaan hukum dalam masyarakat, sebenarnya tidak hanya dapat di artikan sebagai sarana untuk menertibkan kehidupan masyarakat, melainkan juga dijadikan sarana yang mampu mengubah pola

7.Moh Hatta, 2010, Kebijakan Politik Kriminal "Penegakan Hukum Dalam Rangka Penanggulangan Kejahatan", Pustaka Pelajar, Yogyakarta, Hal 5

8. Muladi, 1995, Kapita Selekta Sistem Peradilan Pidana, Semarang, Badan Penerbit Universitas Diponegoro Hal 26

Sangaji Jurnal Pemikiran Syariah dan Hukum 
pikir dan pola perilaku warga masyarakat. Perubahan kehidupan sosial warga masyarakat semakin kompleks, juga mempengaruhi bekerjanya hukum dalam mencapai tujuanya. ${ }^{9}$

Memisahkan hukum dan sosial sangat sulit untuk diwujudkan dalam berbagai pemikiran dalam ciri utama tentang rule of law, juga merupakan pemisahan antara kehendah dengan putusan-putusan terhadap permasalahan hukum, bukan memisahkan antara hukum dan kehidupan sosial yang kita sebut sebagai ruang sosial dalam wilayah hukum dan penegakan hukum itu sendiri, akibatnya yang muncul adalah tawar menawar pemikiran bahwa institusi hukum memperoleh otonom prosedural tanpa memikiran otonomi subtansi hukum tersebut, subtansi hukum itulah yang dikorbankan dalam wilayah penegakan hukum. ${ }^{10}$

Tujuan dari pidana dan tujuan dari pemidanaan bukanlah merupakan bagian dari hukum penitensier, akan tetapi hal-hal tersebut adalah perlu untuk diketahui, yakni untuk dapat mengerti tentang perlunya lembaga-lembaga pemidanaan, lembaga-lembaga penindakan dan lembaga-lembaga kebijaksanaan yang akan dibicarakan selanjutnya dan telah diatur di dalam berbagai peraturan perundang-undangan oleh pembentuk Undang-undang kita. Pada dasarnya terdapat tiga pokok pemikiran tentang tujuan yang ingin dicapai dengan suatu pemidanaan, yaitu untuk memperbaiki pribadi dari penjahatnya itu sendiri, untuk membuat orang menjadi jera untuk melakukan kejahatan-kejahatan dan untuk membuat penjahat-penjahat tertentu menjadi tidak mampu untuk melakukan kejahatankejahatan yang lain, yakni penjahat-penjahat yang dengan caracara yang lain sudah tidak dapat diperbaiki lagi.

9. Edi Setiadi 2010 Hukum Pidana Ekonomi, Yogyakarta,Graha Ilmu Halaman 16

10.Philippe Nonet \& Philip Selznick, 2013, Hukum Responsif, Yang Di Alihbahasakan Oleh Raisul Muttaqien, Nusa Media, Bandung, Hal 1 
Teori-teori yang berusaha mencari dasar pembenaran dari suatu pidana semata-mata pada satu tujuan tertentu masih dapat dibagi menjadi dua macam teori, yakni Teori-teori pencegahan umum atau algemene preventie theorieen, yang ingin mencapai tujuan dari pidana yaitu semata mata dengan membuat jera setiap orang agar mereka itu tidak melakukan kejahatan dan teori-teori pencegahan khusus atau bijzondere preventie theorieen, yang ingin mencapai tujuan dari pidana itu dengan membuat jera, dengan memperbaiki dan dengan membuat pejahatnya itu sendiri menjadi tidak mampu untuk melakukan kejahatankejahatan lagi.

Dalam menafsirkan tujuan pemidanaan perlu mendapatkan perhatian khusus, agar selaras dengan tujuan hukum itu sendiri, selama ini masalah pemidanaan kita selalu berfokus pada berapa banyak hukuman yang dijatuhkan kepada seorang pencuri, meski setelah hukuman itu dijatuhkan pencuri tersebut justru akan melakukan pencurian yang lebih besar. Atas dasar itu muncul pertanyaan yang paling mendasar yakni untuk apa hukuman yang banyak kalau manusianya tidak pernah berubah, harusnya dalam konsep pemidanaan kita perlu menjelaskan tentang tujuan pemidanaan yang memberikan ketertiban sosial, seperti pola pikir dan perilaku manusia yang harus kita perbaiki melalui pemidanaan itu sendiri.

\section{Kesimpulan}

Berdasarkan temuan dalam penelitian ini dapat di simpulkan sebagai berikut:

1. Pemikiran abolisionisme ini dapat dijadikan dasar perubahan paradigma dalam pemberian sanksi pidana melalui peradilan pidana, dari model pemidanaan yang bersifat fisik menuju model pemidanaan yang bersifat psikis, hal ini bertujuan untuk memberikan keseimbangan hukum yang bermuara pada tegaknya nilai keadilan dan ketertiban masyarakat,

Sangaji Jurnal Pemikiran Syariah dan Hukum 
sehingga harusnya dalam konsep pemidanaan kita perlu menjelaskan tentang tujuan pemidanaan yang memberikan ketertiban sosial, seperti yang harus diperbaiki itu adalah pola pikir dan perilaku manusia melalui pemidanaan itu sendiri, paham abolisionisme mencoba merubah pandangan manusia dari pemidanaan yang berfokus pada pemidanaan fisik menuju pemidanaan psikis, sebagai bagian dari tujuan pemidanaan.

2. Kebijakan pembaharuan hukum dalam sistem peradilan pidana sebetulnya tidak hanya memaksimalkan perlindungan terhadap martabat dan hak asasi manusia, akan tetapi haruslah di arahkan perubahan pola pikir dan perilaku manusia sebagai warga negara Indonesia untuk dapat memahami kebijakan hukum yang dapat menanggulangi kejahatan manusia, untuk pembangunan hukum pidana Nasional, lebih khusus yang berkaitan dengan pembaharuan model pemidanaan fisik menuju pemidanaan psikis. 


\section{Daftar Pustaka}

Barda Nawawi Arief, 2010, Kebijakan Legislatif dalam Penanggulangan Kejahatan dengan Pidana Penjara, Genta, Yogyakarta

Edi Setiadi 2010 Hukum Pidana Ekonomi, Yogyakarta, Graha Ilmu.

Jhonny Ibrahim, 2014, Teori dan Metodologi Penelitian Hukum Normatif, Banyumedia Publishing, Surabaya

Moh Hatta, 2010, Kebijakan Politik Kriminal "Penegakan Hukum Dalam Rangka Penanggulangan Kejahatan", Pustaka Pelajar, Yogyakarta

Muladi, 1995, Kapita Selekta Sistem Peradilan Pidana, Semarang, Badan Penerbit Universitas Diponegoro

Philippe Nonet \& Philip Selznick, 2013, Hukum Responsif, Yang Di Alihbahasakan Oleh Raisul Muttaqien, Nusa Media, Bandung

Romli Atmasasmita, 2010, Sistem Peradilan Pidana Kontemporer, Jakarta, Kencana

Soerjono Soekanto, 2002, Pengantar Penelitian Hukum, UI Press, Jakarta

Suteki, 2013, Desain Hukum Di Ruang Sosial, Thafa Media, Bantul Yogyakarta

Wiryono Prodjodikoro, 1986, Asas-asas Hukum Pidana di Indonesia, Eresco, Bandung

Sangaji Jurnal Pemikiran Syariah dan Hukum 